\title{
ASSESSMENT OF THE FORUM ON CHINA-AFRICA COOPERATION (FOCAC) AND THE SIGNIFICANCE OF THE FIRST BEIJING SUMMIT (2000) TO AFRICA
}

\section{Sheriff Ghali Ibrahim, Ahmet Arabaci and Ibeh Doris Chinelo}

Department of Political Science and International Relations, University of Abuja

Department of Political Science and International Relations, Nile University of Nigeria

Email: sherfboy@yahoo.com Phone: +234-7063372013

\section{Cite this article:}

Sheriff G.I., Ahmet A., Ibeh D.C. (2021), Assessment of the Forum on China-Africa Cooperation (FOCAC) and the Significance of the First Beijing Summit (2000) to Africa. Journal of Advanced Research and

Multidisciplinary Studies 1(2), 18-24. DOI: 10.52589/JARMSJHFEVAE8.

\section{Manuscript History}

Received: 3 Sept 2021

Accepted: 28 Sept 2021

Published: 12 Oct 2021

Copyright $(2020$ The Author(s). This is an Open Access article distributed under the terms of Creative Commons AttributionNonCommercial-NoDerivatives 4.0 International (CC BY-NC-ND 4.0 ), which permits anyone to share, use, reproduce and redistribute in any medium, provided the original author and source are credited.
ABSTRACT: This study assessed FOCAC and the significance of the first Beijing Summit resolutions to Africa. The paper adopted developmental research design and qualitative method of data collection by means of secondary data. The study also leveraged on complex interdependence theory as a framework for analysis. The study found out that the Beijing Summit resolution to Africa organized in the year 2000 laid the foundation of mutual cooperation and assistance for the forum on China-Africa cooperation. Assessing the significance of the summit in consonance with the aims and objectives of FOCAC, as highlighted at the summit, it was found out that the summit was significant not only in the areas of debt cancellation and establishment of African human resource development fund and investment, but also in the areas of boosting rapid development of overall cooperation, leading a new type of international cooperation with Africa, promoting democratization of international relations and improving global governance on the principle of win-win cooperation. The paper lamented that there are some challenges faced by FOCAC and recommendations were provided.

KEYWORDS: Resolution, Cooperation, Interdependence, WinWin Diplomacy, FOCAC, Multilateralism. 


\section{INTRODUCTION}

With the decolonization and liberation of Africa from colonial domination, Africa has been struggling to plan for the development of the continent. In the post-independence struggle, Africa has been on its own without fruitful aid that would pave a way for its educational expansion, industrialization, science and technological breakthrough. The foreign aid hitherto given to Africa by her former colonial masters and their allies was not geared towards meaningful development as the donors were not ready for African development and the African leaders were nothing but stooges for perpetual economic imperialism (Sheriff \& Aliyu, 2016).

The emergence of China as a new global economic power, being the second largest economy in the world, built certain confidence in African countries as China was seen as a new partner in political, economic and socio-cultural relations in contemporary global order. The similarities that China and Africa share in many areas triggered further cooperation and representation of the developing countries of the world (Sheriff \& Aliyu, 2016). China has therefore taken the lead in establishing a forum on China-Africa cooperation on the principle of win-win benefits (Sheriff, 2012).

The Forum on China-Africa Cooperation (FOCAC) is an effective platform and multilateral mechanism for China and African countries to conduct collective consultations and carry out pragmatic cooperation. (Aiping \& Zhan, 2018). Since its establishment in 2000, seven ministerial conferences have been convened every three years. Also, in September 2018, China and African countries held their third summit and the seventh Ministerial Conference again in Beijing, which generated profound influence on the FOCAC mechanism development. In 2020, FOCAC clocked 20 years of its existence, having passed through different declarations, action plans, summits and conferences such as the Beijing Declaration in 2000, the Addis Ababa Action plan, the 2006 Beijing Action plan, the Shermel Sheikh Summit of 2006, the fifth FOCAC Conference in Beijing (2012), the Johannesburg Summit of 2015 and lastly, the 2018 Summit and Ministerial Conference in Beijing. In the light of the above background, this study sets out to examine the significance of the First (year 2000) Beijing Summit resolutions to Africa alongside its focal aims and objectives of its formation, and challenges facing FOCAC.

\section{Material and Method}

The study adopted developmental research design being a product of library research. Data were collected qualitatively by means of secondary data sources especially those in books, journals, periodicals and the internet to examine and analyze the issues at hand. Several books, journals, and internet sources were consulted and reviewed to add value to the paper.

\section{LITERATURE REVIEW}

Conceptual Review: Multilateralism is conceptualized as an alliance of multiple countries pursuing a common goal. In other words, it is the direct opposite of unilateralism and bilateralism. It simply means the coordinated diplomatic interaction of three or more states or other actors in international relations. This indicates a form of cooperation between at least three states (Liman, 2008). Multilateralism is a concept in international relations which has to do with the relation(s) that exists among several countries. Etymologically, multilateralism, as argued by Liman (2009), became a common mode of inter-state relations towards the late 
nineteenth century. Prior to that time, it was limited to either special meetings called at moments of crises when war threatened or peace conferences following major wars such as the Congress of Vienna (1815) in which winners and losers of the war gathered to determine the division of the spoils and to settle other matters.

Meanwhile, the prevalence of multilateralism in the 20th century is associated with a number of factors such as proliferation of inter-governmental organizations at the global and regional levels, which provide institutional settings for the conduct of multilateral engagement and the existence of many less-developed countries that rely heavily on UN and other multilateral fora for the bulk of their diplomatic contacts (Pearson \& Rochester, 1988). Today, the concept of multilateralism has been institutionalized in the UN and its specialized agencies. Hence, since the world system is now multipolar, interactions among nation-states are taking place on the principle of complex interdependent cooperation. Thus, one of the products of multilateralism and complex interdependence is the Forum on China-Africa Cooperation (FOCAC).

Empirical Review: The 2000 Beijing Summit's Resolution to Africa/Beijing declaration on China-Africa Cooperation has been a major breakthrough in laying a solid foundation for such a relationship (Sheriff, 2016). The Beijing declaration was meant to conduct equal-footed consultation, deepen understanding, broaden consensus, strengthen friendship and promote cooperation between China and Africa. In the first conference of 2000 held in Beijing, a proposal for new China-Africa partnership was embraced, which was formed to deal with long term stability, equality and mutual benefit (Akugizibwe, 2012). It was also aimed to achieve these objectives: to facilitate economic setting and trade cooperation between the two sides, to formulate some concrete measures like setting up a special fund for Africa's development, offering assistance in infrastructure construction, etc.

Some of the major achievements of the Beijing Summit resolution to Africa are the cancellation of RMB 10.9 billion debts for 31 African countries, the establishment of African human resource development fund, training of about 7,000 African professionals and providing special funds to support and encourage investment by Chinese enterprises in African countries (Barney \& Jamil, 2009). Undoubtedly, the presence of China in Africa and cooperation between the two parties has improved agriculture in Africa, education in Africa, energy in Africa, infrastructure, health and has even boosted the African economy (Beri, 2007; Sheriff, 2016).

Through this forum, China played significant roles in Africa, for example the outbreak of Ebola in Africa where the Chinese government deployed a team of medical professionals to contribute in seeing the end of the epidemic. China is indeed a party to cooperate with in recent times for their humanitarian gesture in Africa against a deadly virus that would have swept the whole continent (Sheriff, 2016). Beyond the surface level, the thrust of this study is to dig into the significance of this first Beijing Summit resolution as the basis of FOCAC. Thus, it is pertinent to state that it was at the summit that the aims and objectives of the forum were spelt out. Against this background, the paper sets out to assess the significance of the summit alongside the objectives. 


\section{Theoretical Framework}

This paper adopts complex interdependence theory. The theory of complex independence was brought to fore by Robert Keohane and Joseph Nye (1977) as a neoliberal critique of the realist view or explanation of the world. The theory is anchored on the proposition/assumption that states and their fortunes are inextricably tied together in the form of cooperation to achieve certain tasks. It focuses on multiple channels, absence of hierarchy among issues and minor role of military force (Rdna, 2015).

Furthermore, foreign policy in the era of interdependence is distinct owing to the multiple and layered channels connecting societies. Also, states are not the unitary or sole actors as realists have assumed Bureaucrats as well as non-governmental elites meet to negotiate and coordinate global understanding and policies. Hence, these layers of interactions are more complicated and multifaceted than realists tend to acknowledge. Keohane and Nye (1977) argue that transnational communications reinforce. Emphasis is placed on absence of hierarchy and the agenda of interstate relations consists of multiple issues that are not arranged in a clear or consistent hierarchy. Finally, domestic interest, frequent and multi-layered interactions across state boundaries, overlapping issues that often lack hierarchy, and decreasing efficacy of military power are hallmarks of complex interdependence and cooperation, and international regimes will prove to be vital to managing such a complex system. Hence, it is based on these theoretical postulations and gesticulations that analysis in this paper revolves.

The topic can also be explained by the international cooperation project, which argues that cooperation can be achieved by partners of like minds. Sheriff, Bibi and Abdulkarim (2021) believe that it is discernible that China, Africa and the entire world, have one major goal, which is a mutual or collective benefit of the cooperation that binds them together. The second aspect of the above analogy is assistance, where people look at American aid to third world states, concluding that it is not without interest; the Chinese assistance to Africa is described as "aid oriented towards helping the other party to realize his/her own goals.

\section{FINDINGS AND DISCUSSION}

Nations and states do not get into relationships that are not significant and important to their existence and survival. Some of the vital areas of significance in the first Beijing summits resolutions are as follows:

\section{a. Boosting rapid development of overall cooperation}

The forum has promoted the traditional Sino-Africa relationship in the political area, and led the all-round development of China-Africa cooperation. It has led to a fast increase in trade between China and Africa as China is seen as the biggest trading partner with Africa since 2009. The trade volume was $\$ 170$ billion and Chinese enterprises' non-financial direct investment in Africa reached $\$ 3.1$ billion in 2017. China has become one of the most significant sources of finance and investment for African countries. (Aiping \& Zhan, 2018). Driven by the forum's measures, more Chinese government-owned and private companies have made their investments in Africa. By 2017, there had been more than $\$ 100$ billion worth of Chinese investment and finance in Africa. 
In Kenya, Djibouti, Mozambique, Ethiopia the Democratic Republic of the Congo, Zambia, Algeria and Côted'Ivoire, China has become the main source of foreign direct investment (Aiping \& Zhan, 2018). Specially, the China-Africa infrastructure cooperation has seen significant achievements. China has undertaken the construction of several highways, railways, port, bridges, airports, hydropower, stations, telecommunication infrastructure and natural gas pipelines projects in Africa, which has commuted the beginning of African countries' integration and economic takeoff. Infrastructure construction has become the best-known brand of China-Africa cooperation, and also the largest factor for China's positive image in Africa. By 2017, China had financed and built for Africa 6,200 kilometers of railways, 6,500 kilometers of road, 20 seaports, 20 bridges, over 80 power plants, more than 200 schools, and 80 plus stadiums. The former President of the African Development Bank, Donald Kaberuka, states that China is the biggest investor in Africa's power infrastructure construction. China and Africa have also constructed many economic and trade cooperation zones, industrial parks, export processing zones and special economic zones together, which provides Chinese enterprises with good platforms to invest in Africa (Aiping \& Zhan, 2018).

\section{b. Leading a new type of international cooperation with Africa}

The FOCAC has reconstructed the paradigm of international cooperation with China, which has demonstrated another policy and development model for cooperation with Africa. It has also offered African countries a new system of partnership guided by the principle of "sincerity, real results, affinity and good faith," courtesy of the Beijing Summits in the year 2000. China has always treated Africa as equal partner despite their size, and aimed at mutual benefits, common development and a win-win outcome. China has promoted Africa's renovation in governance experience, and development concepts. Under the FOCAC's influence, Brazil, South Korea, Turkey, India and other emerging developing countries have been boosting cooperation with Africa and holding similar forums. Even the United States, Europe, and Japan have felt the pressure and increased their investment in Africa, while adjusting and revising their different Africa policies, for the sake of improving their glamour to African countries. In order to respond to the strong demands from African countries, Japan followed the FOCAC and held the sixth Tokyo International Conference on African Development, and promised to shorten the conference's interval from five to three years (Aiping \& Zhan, 2018).

\section{c. Promoting democratization of international relations and improving global governance}

The FOCAC is an exponent of the Chinese concept of "building a new type of international relations with win-win cooperation at the core." In the history of humans, international relations had been permeated with power politics and hegemony. In traditional international relations based on strength and power, the strong never seriously considered equality, mutual benefits or win-win outcomes. On the contrary, China and Africa have been following the principles of equality and mutual assistance since the beginning of their foreign relations. The spirit of equality and mutual respect in China-Africa relations has become a model, representing a new trend in the development of international relations. Since Africa is a significant player in international politics, the natural alliance of China and Africa has boosted the multipolarization and democratization of international order. However, Africa's development has long been a major focus of global governance. Driven by the FOCAC, the UN, G20, BRICS and other international mechanisms are paying increased attention to African problems. To 
make greater contributions to global governance, the FOCAC needs to hold a strong faith in contributing to the common development of mankind. (Aping \& Zhan, 2018).

\section{Challenges Facing FOCAC}

According Haifang (2012), there are some problems facing FOCAC that need to be addressed. Some of these challenges are:

A) Weakness of China's Foreign Assistance: China has constantly increased the intensifying and scale of its foreign assistance. Therefore, there is no coordination among ministries, there is no transparency of assistance and scientific project verification, and this is due to lack of unified coordination and professional management.

B) African Initiative: Presently, FOCAC is directed by China. Though it respects the interest of African states in the decision making process and follows the principle of equal consultation, there are still numerous proposals and policies that are made on the basis of one-sided Chinese dynamism. As a result of this, they do not rest on a foundation of diversity born of multiple channels.

\section{CONCLUSION AND RECOMMENDATIONS}

For China and Africa relationship, the growth of their win-win cooperation of mutual benefits is an irreversible course. The forum has promoted China and Africa relationship in political areas and increased trade between them as China is seen as the largest trading partner in Africa. The government should help speed up legislation on foreign assistance by approving a state council law to control foreign assistance which should be delivered within the settings of international cooperation and boosting multilateral cooperation. The government should create equal consultations on decision making process in the interest of both China and Africa.

\section{REFERENCES}

Aiping, Z. and Zhan, (2018) Origin, Achievements, and Prospects of the Forum on ChinaAfrica Cooperation China International Studies. Vol. 3 No. 4, Sep/October, 2018.

Akugizibwe, F. (2012). The Rise of China-Africa. http//mg.coza/article/2012-17-08DeepRead. The Rise of Chinuafrica accessed on 15 September

Barney, J. and Jamil, A. (2009) China Pledge \$10 Billion in Low-Cost Loans to Africa. The Washington Post November 26.

Beri, R. (2007) China's Rising Profile in Africa. China Report, 43, No3: 297-308

Haifang Liu (2012). FOCAC twelve years later; Achievements, Challenges and The way forward. Peeking University

Keochane, R. O. and Nye, J. S. (1977). Power and Interdependence World Politics in Transition Boston: Little; Brown \&Co.

Koechane, R. O. (1984). After Hegemony: Cooperation and Discord in the World Political Economy, Princeton. NJ: Princeton University Press. 
Liman, A. (2008). Bilateral and Multilateral, Negotiation Diplomacy: An Overview of Global Trends, in Internal Affairs Quarterly. Vol. 1 No. 1 September- October

Nye, J.S. (1990) Bound to Lead: The Changing Nature of American Power: New York: Basic Books

Peason, F.S. and Rocheeter, J. M. (1988). International Relations. The Global Condition in the Late Twentieth Century ( $2^{\text {nd }}$ Edition) New York Random House.

Rdna, W. (2015) Theory of Complex Interdependence: A Comparative Analysis of Realist and Neoliberal Thoughts in International Journal of Business and Social Science Vol. 6, No. 2 February.

Sheriff, G. I. (2012). Sino-African Economic Relations in the New World Order: Competitive or Paternalistic, in Journal of Legislative Studies and Governance Vol. 1, No 3 September-December

Sheriff, G. I. (2016) Reflections in China Nigeria Cultural Relations. Abuja, Digit Link Xtra Ltd.

Sheriff, G.I., Bibi, F.I.B. and Abdulkarim, A. (2021). The Belt and Road Initiative and the Implementation Of the Africa Continental Free Trade Area (AFCFTA) in an Emerging Regional Arrangement. Journal of Global Economics and Business, Volume 2, Number 4, PP.2735-9352.

Walker, T.C (2013). A Circumspect Revival of Liberalism: Robert O. Keohane and Joseph S. Nye Power and Interdependence in B. Henrick; S. Casper and W. Peter (eds) Classics of International Relations: Essays in Criticism and Taylor and Francis Hoboken, ISBN: 9781135018665. 